\title{
PLASTINATION: A NOVEL APPROACH TO CADAVAR SCARCITY IN NIGERIA
}

\author{
${ }^{1}$ OYEWOPO AA, ${ }^{2}$ ADELEKE OS, ${ }^{2}$ TOKUNBO OS, ${ }^{2}$ FALANA BA, ${ }^{1}$ JOHNSON 0 \\ ${ }^{1}$ Department of Anatomy, Faculty of Basic Medical Sciences, University of Ilorin, PMB 1515, Ilorin, Kwara \\ State, Nigeria. \\ 2Department of Anatomy, Faculty of Basic Medical Sciences, College of Health Sciences, Osun State \\ University, PMB 4494, Osogbo, Osun State, Nigeria. \\ Correspondence to Dr. ADELEKE O.S Phone number +2348131323268, email: \\ opeyemi.adeleke@uniosun.edu.ng
}

\section{ABSTRACT}

Cadaveric dissection has always been an integral part of medical education being used for teaching Anatomy, Surgery, Pathology, Radiology, Medical and Biomedical Research in Nigeria higher institutions of learning. However, it is undeniable that Nigeria Universities had been facing a lot of challenges in acquiring cadavers. In view of this scarcity of bodies, organs and tissues for studies, teaching and research, newer techniques of preserving biological tissues for long duration such as plastination is important. Thus, this review elaborates and identifies problems in cadaver acquisition in Nigeria, suggests better preservative technique of cadaver and identifies possible limitations to the practice of the suggested technique and proper possible solutions to the limitations.

Keywords: Plastination, Cadaver, Anatomy, Preservative

\section{INTRODUCTION}

In almost all the health science institutions in Nigeria, cadaveric dissection has always been an integral part of medical education. The cadavers, apart from being used for instructing medical and other health science students, they are also being used for research by medical and biomedical professionals for the development of new surgical procedures, advance operative techniques, therapeutic advancement in medical science and special anatomical studies.

There has been increased scarcity of cadavers in the last decade which has also seen a steep rise in the number of medical institutions and students. A lot of challenges are linked with cadaver acquisition in Nigeria. Some Problems identified in cadaver acquisition included: religion, bottleneck acquisition procedures, culture, ignorance and love even after death (Ewonubari et al., 2012).

Religion and Culture

Muslims and Christians believe that once a person dies, his soul is released to be judged by God and either sent to heaven or hell. Traditionally, most Nigerian tribes believe that a dead person can be reborn and come back as someone's relative while traditional religions believe that a dead person has to be buried with appropriate and befitting ceremonial rites so as to prevent the dead spirit from coming back to haunt the living (Jane, 2017).

\section{Bottleneck acquisition procedures}

The Anatomy act regulates the use of dead bodies for medical purposes and the supply of

Submitted $25^{\text {th }}$ October 2017. Published online $28^{\text {th }}$ February 2018. To cite: Oyewopo AA, Adeleke OS, Tokunbo OS, Falana BA, Johnson O. Plastination: a novel approach to cadavar scarcity in Nigeria. Anatomy Journal of Africa. 2018. Vol 7 (1): $1175-1180$ 
unclaimed bodies to the hospitals and teaching institutions for the purpose of anatomical examination and dissection and other similar processes. However, there are stringent administrative and bureaucratic procedures that make acquiring these bodies cumbersome because several documents have to be processed before these bodies can be released to institutions for teaching and research purposes.

\section{Ignorance and love even after death}

Many countries have understood that cadaver shortage can only be addressed with establishing bequest program centers, which are contributing effectively to cause shift in awareness and attitudes toward organ and body donation (Groscurth at al., 2001; Gunderman, 2008; Boulware et al., 2004). The term "body donation (Lagwinski et al., 1998) is defined as when one passes away, the family members bequeath one's body for medical education and research purposes without any compensation in any form for doing so with a motto of preserving public health". This is not a common practice in Nigeria as family members of the deceased believe that proper burial is an act of love and respect for the deceased.

Besides the aforementioned factors, there is also the problem of decay, which is a vital process in nature but an impediment to morphological studies, teaching, and research (Mehra et al., 2003). This is especially true for biological specimens that shrink significantly when exposed to normal atmospheric conditions. Hence, it has continually been a goal to find suitable preservation techniques.

The most frequently used method of preserving specimens is by suspension in fixatives such as formalin-based solution as open, wet preparations, or by enclosure in glass or Perspex "pots" (Slater, 1981).

Open specimens are unpleasant to work with due to offensive odors, skin and eye irritation as a result of emitted formalin vapors. Students are also unwilling to examine or handle such specimens. The available ones also decompose after a short time.

As a result of this scarcity of bodies, organs and tissues for studies, teaching and research, renew technique of preserving biological tissues for long time such as plastination is important. Thus, this review elaborates and identifies problems in procurement of cadaver in Nigeria, suggests better preservative techniques of cadaver, identifies possible limitations to the practice of the suggested technique and proffer possible solutions to the limitations.

\section{PLASTINATION}

Plastination has become known as a ray of hope for near ideal preservation of biological specimens. It is the process by which water and lipids in biological tissues are been replaced by polymers (such as silicone, polyster, epoxy) which harden subsequently to yield dry, durable and light weight specimens (Pashaei, 2010; O'Sullivanand Mitchell, 1995; Von Hagens, 1986). It is used in anatomy to preserve bodies or body parts.

Professor Gunther Von Hagens, a German born Physician and Anatomist, invented the process in 1977 by preserving several human and animal bodies by plastination (Von Hagens et al., 1987; Von Hagens, 1979). After receiving patents from US government, Hagens established Institute for Plastination in 1993 and displayed the first exhibition of plastinated bodies' tagged "Body world" at Japan in 1995 which drew over three million people (Pashaei, 2010). Plastinated specimens are dry, durable, odourless, flexible, lifelike and aesthetically pleasing.

Apart from large space, ventilation, vigilance and technical know-how, Plastination requires deep freezers, vacuum chamber with pump, gas curing chamber, airtight containers and other materials as Polyvinyl chloride (PVC) pipes, glass rods, glass sheets, clamps etc. (Torre et al., 2004). Consumables or chemicals required are curable polymers (such as silicone S3, S6, S10; polyester; epox; polypropylene; cyanoacrylates; araldite), acetone or ethanol (as dehydrating agents), hardeners (such as S3, gas cure S6). Many of these polymers, hardeners and curing 
agents are patented by Gunthur"sBiodur $\AA$ Company and have to be imported. Use of other polymers such as araldite is being experimented and is used successfully at some places. Care needs to be exercised as acetone vapours are highly inflammable and leakage has to be prevented.

There are basically three (3) types of plastination based on the density, shape, size and nature of the tissue. The whole organ or body of an animal can be totally plastinated using silicone (S10) and polypropylene resins as impregnating agents (Whole organ or body type of plastination). Lungs, intestines, kidneys, stomach e.t.c which are hollow organs can be plastinated using luminal cast type of plastination while sheet type of plastination makes use of thin transparent or thick opaque sections of an organ or body and display it in cross sectional anatomy similar to MRI or CT scan sections (Pashaei, 2010; vonHagens et al., 1987; vonHagens, 1986).

\section{Standard Technique in Plastination}

Plastination is the process of permanently preserving tissue in a "life-like" state by replacing the body fluids (i.e. fat and water) with synthetic materials. The S10 technique is the standard technique in plastination. It results in opaque, more or less flexible, and natural looking specimens (Pashaei, 2010). The standard plastination process consists of four sequential steps viz. Fixation, Dehydration, Forced Impregnation in vacuum and Curing (hardening) (Bickley, 1984).

Fixation can be done by almost all conventional fixatives (Pashaei, 2010). Dehydration is carried out successfully mainly by acetone because acetone also serves as the intermediary solvent during impregnation (Srisuwatanasagul et al., 2010). Forced impregnation is the most important step in plastination: vacuum forces the acetone out of and the polymer into the specimen (Pashaei, 2010). Hardening also known as curing is the final step where the impregnated specimen is hardened by exposing it to a gaseous hardener (silicone), or by Ultra Violet A-light and heat (Pashaei, 2010).
Plastinated specimens are perfect for teaching, particularly for neuroanatomy (Latorre et al., 2007). Silicone plastinated brains are useful because they can be grasped literally and they are almost everlasting (Riederer, 2014). Polyester plastination of brain slices provides an excellent distinction of gray and white matter and thus a better orientation (Latorre et al., 2007). Other methods of plastination include:

1. The COR-TECH - Room Temperature Procedure in which the samples/organs are impregnated with several polymers, cross linker and catalyst at room temperature as against $-25^{\circ} \mathrm{c}$ required for standard S10 technique (Raof et al., 2013).

2. The Epoxy E12 Procedure which is usually used for thin, transparent, and firm body and organ slices (Pashaei, 2010).

3. The Polyester P35/P40 Procedure which is usually used for semitransparent and firm brain slices (Henry, 2004).

4. Light weight plastination procedure which requires use of xylene, silicone and small quantity of resin thereby making the procedure to be cost effective (Steinke et al.,2008)

5. The Quickfix ${ }^{\circledR}$ Procedure uses a combination of Quickfix $\AA$ and amylacetate solution for organs impregnation (Mehra et al., 2003).

6. Melamyne Procedure uses melamine (polymer used for impregnation) and xylene (used to degrease formalin fixed, acetone dehydrated specimens) for organs plastination (Chandel et al., 2013)

\section{Applications and advantages of Plastinated Specimen over the Convectional Formalin Fixed Specimen}

Formaldehyde can be toxic, allergenic and carcinogenic (Binawara et al., 2010; Hauptmann et al., 2009). Exposure occurs primarily by inhalation, or via skin absorption of formaldehyde containing fluids. Disorders of 
exposure include airway irritation and obstructive disorders such as bronchial asthma (Binawara et al., 2010), ocular irritations, corneal clouding (Raja, 2012), leukemia, nasopharyngeal cancers (Hauptmann et al., 2004), spontaneous abortions, congenital malformations (Raja, 2012), and menstrual irregularities (Khaliq and Tripathi, 2009). Moreover, it has been documented as an allergic skin sensitizer that may lead to dermatitis (Keil et al., 2001).

The toxicity of formaldehyde gets worse by the tendency of the exposed individuals to develop tolerance within a few hours of exposure. Accordingly, those individuals remain in environments of gradually raised formaldehyde concentrations without being appreciative of the increased exposure levels and consequent hazards (Emue et al., 2011).

Plastination is increasingly finding applications in the varying fields. The plastinated specimens are near ideal and are excellent for teaching gross anatomy, neuroanatomy (where routine specimens are delicate and sparse). Silicon casts of ventricular system of brain and tracheobronchial tree can be utilized for teaching. The anatomical structure and relations are well preserved and appear like fresh specimens (Henry, 2004). The specimens are dry, durable, odourless, light weight, non-toxic and non-infectious. They are convenient to handle, store and transport. Thin sections of specimen made by sheet plastination preserve the microscopic structure of the tissues (Henry, 2004). Plastinated specimens can also be used for both light microscopy and ultrastructural studies after deplastination with sodium methoxide (Grondin et al., 1994). Sheet plastination bridges the gap between histology, radiology and gross anatomy. Surgically removed tissues and pathological specimens can be preserved by plastination for teaching and research. Plastinated animal gastrointestinal tract and tracheobronchial tree can be utilized to teach endoscopic techniques (Kamath et al., 2013). Exhumed mummies, rare animals or archeological materials can be plastinated for museum display. The technique can preserve tissue sample to be used as medicolegal evidence (Ravi and Bhatt, 2011).

One research conducted in Vellore, India mentioned that plastination serves the best method in obtaining more durable specimens due to difficulties in obtaining human cadaver for teaching anatomy (Suganthy and Francis, 2012). The study correspondingly revealed that plastinated specimens are preferable as they are devoid of formalin smell and easier to be handled. The same study as well reported that plastinated specimens enable them to understand the exact structure relations that would be damaged in wet specimens (Suganthy and Francis, 2012).

\section{Limitations to Plastination Practice in Nigeria}

Plastination procedure needs skills, is time consuming and needs quite a few trial and errors by beginner to attain the desired result. The procedure needs expensive and special equipment presently unavailable in the conventional laboratories. Majority of the polymers used in the procedure are patented and need to be imported. Acetone used as intermediary solvent is costly and inflammable needing extra precautions. Though the plastinated specimens are of high quality, they lack the feel and texture that is provided by wet cadavers (Ravi and Bhatt, 2011).

\section{Possible solutions to the Limitations}

The lack of technical knowhow is a major limitation in Nigeria today. There is therefore an urgent need for adequate provision of funds by the government and other stakeholders that will enable medical institutions in the country train their staff in the art of plastination. It is also important to form linkages with countries and institutions for proper knowledge transfer and importation of equipment and consumables that cannot be sourced within the country. 
In conclusion therefore, plastination has a great future in all fields of teaching and research. Natural appearance of the specimens makes the plastination a boon for anatomy learners. It is a good replacement for formalin as a preservative and there are no health hazards.

However, it is irrefutable that plastination has its own shortcomings. The foremost delinquent in constructing plastinated specimens is that it necessitates skills and it is a time-consuming procedure. The procedure requires high financial involvement and special equipment that are unable to find in conventional laboratories. Future research should therefore, target to develop fast and cost effective techniques of plastination.

\section{REFERENCES}

1. Bickley HC. 1984. Plastination: A new technique for anatomic pathology and forensic science. Pathol. Update Series. 2(16):2-8

2. Binawara BK, Rajnee S, Choudhary KC, Mathur H, Sharma K, Goyal. 2010. Acute effect of formalin on pulmonary function tests in medical students. Pak J Physiol. 6:8

3. Boulware LE, Ratner LE, Cooper LA, LaVeist TA, Powe NR. 2004. Whole body donation for medical science: A population based study. Clin Anat. 17:570-7.

4. Chandel CS, Jain A, Chouhan S, Hada R, Jain R. 2013. Plastination by an Acid Curing Polymer at Room Temperature: A Pink City Technique. Int. J. Pure Appl. Sci. Technol. 16(2):39-45

5. Emue BE, Ayanniyi AA, Nwegbu MM, Ibekwe TS. 2011. Acute effects of formalin-treated cadaver on Nigerian medical students. Am J Trop Med Pub Health. 1:89-96

6. Ewonubari EB, Watson JT, Amaza DS, Madueke NM, Donatus AA, Effiong OE. 2012. Problems and prospects of acquistion of human cadaver for medical education in Nigeria. J Pak Med Assoc. 62(11):1134-6.

7. Groscurth P, Eggli P, Kapfhammer J, Rager G, Hornung JP, Fasel JD. 2001. Gross Anatomy in the surgical curriculum in Switzerland: Improved cadaver preservation, anatomical models and course developmemt. Anat Rec. 265:254-6.

8. Gunderman RB. 2008. Giving ourselves: The ethics of anatomical donation. Anat Sci Educ $1(5): 217-219$.

9. Grondin GG, Talbot BG. 1994. A study of criteria permitting the use of plastinated specimens for light and electronmicroscopy. Biotech. Histochem. 69(4): 219-234.

10. Hauptmann M, Lubin JH, Stewart PA, Hayes RB, Blair A. 2004. Mortality from solid cancers among workers in formaldehyde industries. Am J Epidemiol. 159:117-1130

11. Hauptmann M, Stewart PA, Lubin JH, Freeman LE, Hornung RW, Herrick RF, Hoover RN, Fraumeni JF, Blair A, Hayes RB. 2009. Mortality from lymphohaematopoietic malignancies and brain cancer among embalmers exposed to formaldehyde. J Nat Can Inst, 101(24):1696-1708

12. Henry RW. 2004. Polyester plastination techniques, specific troubles and problems. Murcia, Spain, 12th International Conference on Plastination.

13. Jane D. 2017. Nigerian burial traditions. Retrieved online September 29, 2017. Available https://classroom.synonym.com/nigerian-burial-traditions-12084338.html

14. Kamath VG, Shetty RK, Asif M, Ramakrishna A. 2013. A Comparative Study of Tracheobronchial Pattern Using Luminal Plastination. Int J Anat Res. 1(3):161-64.

15. Keil CE, Akbar-Khanzedeh F, Konency KA. 2001. Characterizing formaldehyde emission rates in a gross anatomy laboratory. Appl Occup Environ Hyg. 16:967-972

16. Khaliq F, Tripathi P. 2009. Acute effects of formalin on pulmonary functions in gross anatomy laboratory. Ind J Physiol Pharmacol. 53:93-96 
17. Lagwinski M, Bernard JC, Keyser ML, Dluzen DE. 1998. Survey of Cadaveric donor application files: 1978-1993. Clin Anat. 11:253-262.

18. Latorre RM, García-Sanz MP, Moreno M, Hernández F, Gil F, López O, Ayala MD, Ramírez G, Vázquez JM, Arencibia A, Henry RW. 2007. How Useful Is Plastination in Learning Anatomy? J Vet Med Educ. 34(2):172-176.

19. Mehra S, Choudhary R, Tuli A. 2003. Dry Preservation of Cadaveric Hearts: An Innovative Trial. Journal of the International Society for Plastination. 8:34-36

20. O"Sullivan E and Mitchell BS. 1995. Plastination for gross anatomy teaching using low cost equipment. Surg Radiol Anat. 17(3):277-281

21. Pashaei S. 2010. A brief review on the history, methods and applications of plastination. Int. J. Morphol. 28(4):1075-1079

22. Raja DS. 2012. Potential health hazards for students exposed to formaldehyde in the gross anatomy laboratory. J Environ Health. 74:36-40

23. Raof A, Henry RW, Reed RB. 2007. Silicone plastination of biological tissue: Room temperature technique DowTM/Corcoran technique. Journal of the International Society for Plastination. 22:21-25

24. Ravi SB and Bhatt VM. 2011. Plastination: A novel, innovative teaching adjunct in oral pathology. Journal Oral Maxillofacial Pathology. 15(2):133-137.

25. Riederer BM. 2014. Plastination and its importance in teaching anatomy. Critical points for longterm preservation of human tissue. J Anat. 224(3):309-15.

26. Slater D. 1981. Health hazards of formaldehyde. Lancet. 1(8229): 1099.

27. Srisuwatanasagul K, Srisuwatanasagul S, Adirekthaworn A, Darawiroj D. 2010. Comparative Study between Using Acetone and Absolute Alcohol for Dehydration in Plastination Procedure. Thai J. Vet. Med. 40(4):437-440

28. Steinke H, Rabi S, Saito T, Sawutti A, Miyaki T, Itoh M, Spanel-Borowski K. 2008. Light-weight plastination. Ann Anat. 190(5):428-31

29. Suganthy J and Francis DV. 2012. Plastination using standard S10 Technique- Our experience in Christian Medical College, Vellore. Journal of Anatomical Society of India. 61(1):44-47

30. Torre FR, Rodríguez-Baeza A, Doménech-Mateu JM. 2004. Setting up a plastination laboratory at the Faculty of Medicine of the Autonomous University of Barcelona. Eur J Anat. 8(1):1-6

31. vonHagens G, Tiedemann K, Kriz W. 1987. The current potential of plastination. Anat. Embryol. 175(4):411-421

32. vonHagens G. 1986. Heidelberg plastination folder. Collection of all technical leaflets for plastination. 2nd Edn. Heidelberg, Anatomische Institut, Universität Heidelberg.

33. vonHagens G. 1979. Impregnation of soft biological specimens with thermosetting resins and elastomers. Anat Rec. 194:247-256. 